\title{
Exercise upregulates salivary amylase in humans (Review)
}

\author{
ERI KOIBUCHI and YOSHIO SUZUKI \\ Laboratory of Sports Nutrition and Biochemistry, Graduate School of Health and Sports Science, \\ Juntendo University, Inzai, Chiba 270-1695, Japan
}

Received September 2, 2013; Accepted January 22, 2014

DOI: 10.3892/etm.2014.1497

\begin{abstract}
The secretion of salivary $\alpha$-amylase is influenced by adrenergic regulation of the sympathetic nervous system and the hypothalamic-pituitary-adrenal axis; thus, exercise affects the levels of salivary $\alpha$-amylase. Granger et al published a review in 2007 that focused attention on salivary $\alpha$-amylase. In addition, a portable system for monitoring salivary $\alpha$-amylase activity was launched in Japan at the end of 2005. The correlation between exercise and salivary $\alpha$-amylase has since been extensively investigated. The present review summarizes relevant studies published in the English and Japanese literature after 2006. A search of the PubMed and CiNii databases identified 54 articles, from which 15 original articles were selected. The findings described in these publications indicate that exercise consistently increases mean salivary $\alpha$-amylase activities and concentrations, particularly at an intensity of $>70 \% \mathrm{VO}_{2}$ max in healthy young individuals. Thus, these studies have confirmed that salivary $\alpha$-amylase levels markedly increase in response to physical stress. Salivary $\alpha$-amylase levels may therefore serve as an effective indicator in the non-invasive assessment of physical stress.
\end{abstract}

\section{Contents}

1. Introduction

2. Materials and methods

3. Results and discussion

\section{Introduction}

Salivary $\alpha$-amylase secretion is influenced by adrenergic regulation of the sympathetic nervous system and the

Correspondence to: Dr Yoshio Suzuki, Laboratory of Sports Nutrition and Biochemistry, Graduate School of Health and Sports Science, Juntendo University, 1-1 Hiraga-gakuendai, Inzai, Chiba 270-1695, Japan

E-mail: y_suzuki@sakura.juntendo.ac.jp

Key words: physical stress, sympathetic nervous system, adrenergic, athlete hypothalamic-pituitary-adrenal axis (1). Therefore, exercise may affect salivary $\alpha$-amylase levels.

Granger et al (1) published a review of biobehavioral studies of salivary $\alpha$-amylase in 2007, suggesting that salivary $\alpha$-amylase levels markedly increase in response to physical and psychological stress. Studies by Chatterton et al (2) and Kivlighan and Granger (3) identified that salivary $\alpha$-amylase levels increased in response to exercise. Chatterton et al (2) compared levels of salivary $\alpha$-amylase in males prior to and following exercise, a written examination or rest, and identified that aerobic exercise induced a three-fold mean increase in $\alpha$-amylase levels. Kivlighan and Granger (3) observed that salivary $\alpha$-amylase levels increased by an average of $156 \%$ in 42 members ( 21 females) of a collegiate crew team in response to an ergometer competition.

Following publication of the review by Granger et al (1), various groups investigated the correlation between exercise and salivary $\alpha$-amylase. A portable system for monitoring salivary $\alpha$-amylase activity was launched in Japan at the end of 2005 (4), which stimulated increased interest in the subject. Certain findings were only published in Japanese. The present review aims to summarize previous studies concerning the correlation between exercise and salivary $\alpha$-amylase levels published in the English and Japanese literature.

\section{Materials and methods}

Information was collected from the PubMed (http://www.ncbi. nlm.nih.gov/pubmed/) and CiNii (http://ci.nii.ac.jp/) databases. The latter is a database maintained by the Japanese National Institute of Informatics (Tokyo, Japan), which comprises literature published by Japanese authors in academic journals or university memoirs and is listed in the database of the Japanese National Diet Library (Tokyo, Japan).

The search terms were 'saliva', 'amylase' and 'exercise'. Original studies published after 2006 concerning the effect of exercise on salivary $\alpha$-amylase in healthy humans were selected according to the following exclusion criteria: published prior to 2006; the article was not original; the participants were not healthy; the study was intervention-based rather than exercise-based; salivary $\alpha$-amylase levels/activity were not examined; the language was other than English or Japanese.

The PubMed search identified 42 studies. Fifteen reports were excluded as they were published prior to 2006. Thirteen studies were selected from the titles and abstracts of the remaining 27 publications, according to the aforementioned 


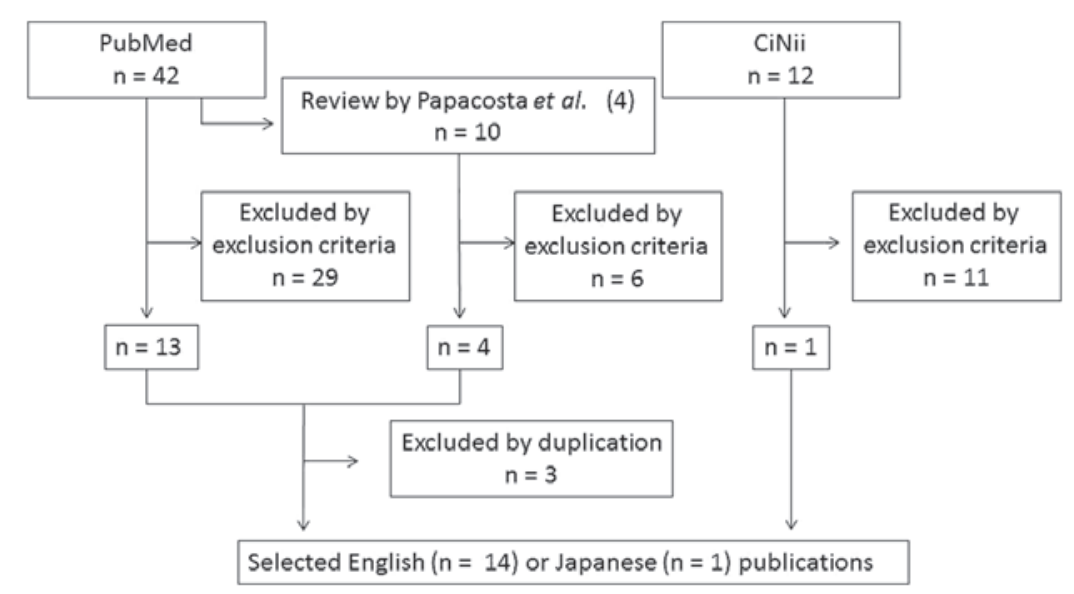

Figure 1. Flow diagram of the literature search and process for selecting original studies that demonstrated a correlation between salivary $\alpha$-amylase levels and exercise in healthy humans.

exclusion criteria. The CiNii search identified 12 studies. One was selected via the same procedure described for the PubMed search. Among the 42 publications obtained from PubMed, one review article by Papacosta and Nassis (5) cited 128 publications. According to the exclusion criteria, four articles were selected from the 10 listed among the references that described the correlation between salivary $\alpha$-amylase and exercise in healthy humans. Three duplicated studies were excluded and the remaining 15 publications were selected (Fig. 1).

Data are presented as the mean \pm SD unless otherwise specified. $\mathrm{P}<0.05$ was considered to indicate a statistically significant difference.

\section{Results and Discussion}

Ten of the 15 publications observed significant increases in salivary $\alpha$-amylase activity or levels in response to exercise, five identified no differences and no studies identified a reduction (Table I).

A simple comparison or meta-analysis was not applicable as the type, duration and intensity of exercise, and the characteristics of the study subjects differed markedly.

Eight studies defined exercise intensity as a ratio (\%) of the maximum or peak oxygen uptake $\left(\mathrm{VO}_{2}\right.$ max and $\mathrm{VO}_{2}$ peak, respectively) or peak power output of the study participants and four used ergometers (6-9) and treadmills (10-13) for exercise loading.

Ergometer exercise was consistently demonstrated to elevate salivary $\alpha$-amylase activity. Bishop et al (6) noted an increase in salivary $\alpha$-amylase activity following exercise at $70 \% \mathrm{VO}_{2}$ peak for $90 \mathrm{~min}$ in endurance-trained males (age $23 \pm 1$ years; mean \pm SEM). Allgrove et al $(7,8)$ conducted two studies using a bicycle ergometer, one of which determined the effect of exercise in ten active males (age, $23 \pm 1$ years; mean $\pm \mathrm{SEM}$ ) at intensities of $50 \% \mathrm{VO}_{2} \mathrm{max}$, $75 \% \mathrm{VO}_{2} \max$ and at incremental loads to exhaustion. The duration was matched to the initial $\mathrm{VO}_{2}$ max test. Levels of $\alpha$-amylase activity increased in all three trials in response to exercise (7). The other study confirmed these results in 24 trained male participants (age, $23 \pm 5$ years) who cycled for $2.5 \mathrm{~h}$ at $60 \% \mathrm{VO}_{2} \max$ followed by $75 \% \mathrm{VO}_{2} \max$ to exhaustion; the mean salivary $\alpha$-amylase activity increased from $143 \pm 23$ to $463 \pm 22 \mathrm{U} / \mathrm{ml}$ (8). Fortes et al (9) observed an increase (not significant) in salivary $\alpha$-amylase activity during exercise at $55 \%$ peak power output at $33^{\circ} \mathrm{C}$, with $\leq 50 \%$ relative humidity; up to $3 \%$ of body mass was lost due to sweat in 13 participants (age $24 \pm 5$ years). The control condition, with rehydration to offset fluid loss, was examined and the kinetics of salivary $\alpha$-amylase activity were almost identical. The participants in these four studies of ergometer exercise were all healthy, with a mean age of 23-24 years. The intensity of the exercise was low in the study of dehydration (9). Allgrove et al (7) showed that $\alpha$-amylase activity increased at $50 \% \mathrm{VO}_{2} \max$ and the study by Fortes et al indicated that the mean $\alpha$-amylase activity increased at $55 \%$ peak power output, although not significantly (9). Thus, exercise on a bicycle ergometer at an intensity as low as $55 \%$ peak power output may elevate salivary $\alpha$-amylase activity.

By contrast, treadmill running generated mixed results. Fortes and Whitham (10) observed that $\alpha$-amylase activity was elevated following running on a treadmill for $30 \mathrm{~min}$ at $50 \% \mathrm{VO}_{2} \max$ followed by $30 \mathrm{~min}$ at $70 \% \mathrm{VO}_{2} \max$, in six endurance-trained males (age, $21.8 \pm 1.9$ years). Leicht et al (11) reported that $\alpha$-amylase activity increased in 23 wheelchair athletes. However, subsequent publications did not confirm these results. According to Costa et al (12), salivary $\alpha$-amylase activity increased, although not significantly, in 11 male endurance runners who ran at $75 \% \mathrm{VO}_{2} \max$ for $2 \mathrm{~h}$. The findings of Rosa et al (13) from a study of 10 active males who ran on treadmills at $70 \% \mathrm{VO}_{2} \max$ for $1 \mathrm{~h}$ supported these results; the mean salivary $\alpha$-amylase concentrations were increased but the increase was not statistically significant. Three of the four studies, with the exception of the study of wheelchair athletes, comprised small cohorts, which may account for this discrepancy.

Five studies demonstrated changes in salivary $\alpha$-amylase in response to exercise without specifying the exercise intensity (14-18). In one of these studies, 12 Caucasian male national-level cyclists underwent a progressive test on a bicycle ergometer. The initial load was $50 \mathrm{~W}$, which increased by $25 \mathrm{~W}$ every $2 \mathrm{~min}$ to exhaustion. The salivary $\alpha$-amylase concentration increased in parallel with the increase in 
Table I. Parameters of primary studies.

\begin{tabular}{|c|c|}
\hline Subjects & Exercise \\
\hline $\begin{array}{l}\text { Endurance-trained } \\
\text { males }(n=11) ; \\
\text { age, } 23 \pm 1 \text { years }^{\text {a }}\end{array}$ & $\begin{array}{l}\text { Bicycle ergometer } \\
70 \% \mathrm{VO}_{2} \text { peak }(90 \mathrm{~min})\end{array}$ \\
\hline $\begin{array}{l}\text { Healthy males }(n=10) \text {; } \\
\text { age, } 23 \pm 1 \text { years }^{\mathrm{a}}\end{array}$ & $\begin{array}{l}\text { Bicycle ergometer } \\
50 \% \text { or } 75 \% \mathrm{VO}_{2} \max \\
\text { or repetition of incremental test } \\
\text { to exhaustion (same duration as } \\
\text { initial } \mathrm{VO}_{2} \max \text { test) }\end{array}$ \\
\hline $\begin{array}{l}\text { Trained male volunteers } \\
\text { with cycling as primary } \\
\text { sport }(n=24) \text {; } \\
\text { age, } 23 \pm 5 \text { years }\end{array}$ & $\begin{array}{l}\text { Bicycle ergometer } \\
60 \%(2.5 \mathrm{~h}) \text { and } 75 \% \\
\mathrm{VO}_{2} \text { max to exhaustion }\end{array}$ \\
\hline $\begin{array}{l}\text { Healthy males }(n=9) \text {, } \\
\text { healthy females }(n=4) \text {; } \\
\text { age, } 24 \pm 5 \text { years }\end{array}$ & $\begin{array}{l}\text { Bicycle ergometer } \\
55 \% \text { peak power output at } 33^{\circ} \mathrm{C} \\
\leq 50 \% \mathrm{RH} \text { up to } 3 \% \text { body } \\
\text { weight loss as sweat }\end{array}$ \\
\hline
\end{tabular}

Healthy endurancetrained males $(n=6)$; age, $21.8 \pm 1.9$ years

Elite male wheelchair athletes $(n=23)$; mean age, 27 years

Male competitive endurance runner $(n=11)$; age, $27 \pm 7$ years

Male, habitual exercise $\geq 3 \mathrm{x} /$ week $(\mathrm{n}=10)$; age, $23.5 \pm 3.95$ years $^{\mathrm{a}}$

Male national-level Caucasian cyclists $(n=12)$; age, $22.62 \pm 3.51$ years

Active males $(\mathrm{n}=21)$; age, $24 \pm 2$ years

Male paraplegic athletes $(n=9)$; age, $44 \pm 2$ years $^{\text {a }}$
Changes in

salivary $\alpha$-amylase

Pre- vs. $45 \mathrm{~min}$ following

exercise and post-exercise:

$441 \pm 81$ vs. $1279 \pm 248$

and $1441 \pm 262 \mathrm{U} / \mathrm{ml}^{\mathrm{a}}$

$\alpha$-amylase activity,

Increase

mean \pm SEM $(\mathrm{U} / \mathrm{ml})$

$50 \% \mathrm{VO}_{2} \max , 450 \pm 54 \rightarrow 552 \pm 77$

$75 \% \mathrm{VO}_{2} \max , 372 \pm 65 \rightarrow 674 \pm 77$

Exhaustion, $456 \pm 65 \rightarrow 710 \pm 41$

Pre- vs. post-exercise

Increase

8

(to exhaustion),

$143 \pm 23$ vs. $463 \pm 22 \mathrm{U} / \mathrm{ml}$

Exercise tended to increase

No change

mean salivary $\alpha$-amylase

activity (NS). Dehydration

decreased secretion rate but, did not influence salivary

$\alpha$-amylase activity

Pre- vs. post-exercise,

$115 \pm 27$ vs. $180 \pm 29 \mathrm{U} / \mathrm{ml}$

Increase

10

$50 \%$ and $70 \% \mathrm{VO}_{2} \max$

(30 min each)

at $30^{\circ} \mathrm{C}$ and $40 \% \mathrm{RH}$

Treadmill,

constant load: $60 \% \mathrm{VO}_{2}$ peak

(30 min $x$ 2)

Intermittent trial: 20 sets of

2 min at $80 \% \mathrm{VO}_{2}$ peak and

$1 \mathrm{~min}$ at $40 \% \mathrm{VO}_{2}$ peak

Treadmill

$75 \% \mathrm{VO}_{2} \max (2 \mathrm{~h} \mathrm{x} 2)$

Treadmill, overnight fast then

$70 \% \mathrm{VO}_{2}$ peak $1 \mathrm{~h}$

after exercise

Cycle ergometer

Initial load of $50 \mathrm{~W}$,

increased by $25 \mathrm{~W}$ every

2 min to exhaustion

Treadmill

3 min warm-up walk

at $0.765 \mathrm{~m} / \mathrm{sec}$,

single exercise test and

$\geq 5$ stages of the Bruce

protocol following $1.5 \mathrm{~min}$ at

peak stage; immediate stop

Handcycle

Self-paced time trial (1 h)
Mean activity elevated but NS

No change

12

Increased following exercise

under constant load and

intermittent trial

Mean salivary $\alpha$-amylase elevated then leveled marginally but NS

No change

Elevated $\alpha$-amylase

Increase

concentration in salivary

proteins

Pre-exercise vs. stop-point:

Increase
Increase

16
Pre- vs. post-exercise

$158 \pm 47$ vs. $281 \pm 72 \mathrm{U} / \mathrm{ml}^{\mathrm{a}}$ 
Table I. Continued

\begin{tabular}{|c|c|c|c|c|}
\hline Subjects & Exercise & $\begin{array}{c}\text { Changes in } \\
\text { salivary } \alpha \text {-amylase }\end{array}$ & $\begin{array}{l}\text { Trend of change in } \\
\text { salivary } \alpha \text {-amylase }\end{array}$ & Ref. \\
\hline $\begin{array}{l}\text { Healthy elderly } \\
\text { males }(\mathrm{n}=7) \text { and } \\
\text { females }(\mathrm{n}=13) \text {; } \\
\text { age, } 64.7 \pm 8.2 \text { years }\end{array}$ & Fitness program for elderly & $\begin{array}{l}\text { Pre- vs. post-exercise (NS) } \\
32.7 \pm 34.0 \text { vs. } 36.3 \pm 34.9 \mathrm{U} / \mathrm{ml}\end{array}$ & No change & 17 \\
\hline $\begin{array}{l}\text { Male university } \\
\text { students; } \mathrm{n}=10 \text {; } \\
\text { age, } 22.2 \pm 0.47 \text { years }\end{array}$ & $\begin{array}{l}\text { Walk (20 min) in a forest } \\
\text { or urban environment }\end{array}$ & $\begin{array}{l}\text { Mean activity increased in the } \\
\text { urban environment and was } \\
\text { unchanged in the forest } \\
\text { environment (NS) }\end{array}$ & No change & 18 \\
\hline $\begin{array}{l}\text { Black belt } \\
\text { taekwondo athletes; } \\
\text { male }(\mathrm{n}=10) \\
14 \pm 0 \text { years } \\
\text { female }(\mathrm{n}=6) \\
\left.(13 \pm 1 \text { years })^{\mathrm{a}}\right)\end{array}$ & $\begin{array}{l}\text { Saliva collected pre- and } \\
\text { post youth competition }\end{array}$ & Elevated during competition & Increase & 20 \\
\hline $\begin{array}{l}\text { Male professional } \\
\text { swimmers }(n=11) \text {; } \\
\text { age, } 21.5 \pm 2.16 \text { years }\end{array}$ & $\begin{array}{l}\text { Saliva samples, collected } \\
\text { on the first day of national } \\
\text { competition and } 2 \text { weeks } \\
\text { after }\end{array}$ & $\begin{array}{l}\text { Increased salivary } \alpha \text {-amylase } \\
\text { levels immediately prior to } \\
\text { warming up and at } 5 \mathrm{~min} \\
\text { after competition }\end{array}$ & Increase & 21 \\
\hline
\end{tabular}

Data are presented as the mean \pm SD unless otherwise specified. ${ }^{\mathrm{a}}$ Mean $\pm \mathrm{SEM}$. $\mathrm{RH}$, relative humidity; $\mathrm{VO}_{2}$ max, maximal oxygen consumption; $\mathrm{VO}_{2}$ peak, peak oxygen consumption at high intensity workload; NS, not significant.

load (14). Galina et al (15) adopted the Bruce protocol test using treadmills. Twenty-one active males performed a single bout of exercise and a minimum of five stages of the Bruce protocol (19). Salivary $\alpha$-amylase activity increased during the exercise and reached the greatest level following the highest completed stage achieved by each participant (15). Allgrove et al (16) examined responses in male athletes with spinal cord damage. Salivary $\alpha$-amylase activity increased from $158 \pm 47$ to $281 \pm 72 \mathrm{U} / \mathrm{ml}$ (SEM) following $1 \mathrm{~h}$ of self-paced handcycling time trials in nine physically active male wheelchair athletes. Ishiguro et al (17) observed changes in $\alpha$-amylase activity among healthy elderly individuals (age 64.7 \pm 8.2 years) during a fitness program comprising a $10 \mathrm{~min}$ warm up, $30 \mathrm{~min}$ of exercise and a $10 \mathrm{~min}$ cool down. The exercise performed was light aerobic gymnastics with singing developed for the elderly and the warm up and cool down consisted of stretching. Salivary $\alpha$-amylase activity were not affected by the program, as pre-exercise values compared with post-exercise values were $32.7 \pm 34.0$ versus $36.3 \pm 34.9 \mathrm{U} / \mathrm{ml}$, respectively. Yamaguchi et al (18) identified that levels of salivary $\alpha$-amylase activity in 10 male university students (age 22.2 \pm 0.5 years) during a 20 min walk, in forest and urban environments, did not change. With the exception of light gymnastics for the elderly (17) and relaxed walking (18), physical exercise appears to increase salivary $\alpha$-amylase activity and concentration (14-16).

Chiodo et al (20) and Diaz et al (21) investigated the effect of Taekwondo and swimming competitions, respectively. Sixteen taekwondo black belt athletes participated in an offi- cial youth competition consisting of three 2-min rounds with 1 -min intervals. Salivary $\alpha$-amylase activity was increased by $115 \%$ at the end of the competition compared with the pre-competition values (20). Diaz et al (21) compared the $\alpha$-amylase concentrations in saliva during a national swimming competition with those two weeks following the event (the control day) in 11 professional swimmers. The $\alpha$-amylase concentrations immediately prior to warming up for the race and $5 \mathrm{~min}$ after finishing were higher than those at the same time on the control day. Thus, psychological and physical stress were considered to contribute to the increase in $\alpha$-amylase levels.

In conclusion, exercise has consistently been shown to increase mean salivary $\alpha$-amylase activity and concentration in all studies examined in the present review, including those in which changes were not significant, with the exception of the 20-min forest walk (18). The effect tended to be more pronounced at exercise intensities $>70 \% \mathrm{VO}_{2} \max$ in healthy young individuals. Therefore, studies published following those reviewed by Granger et al (1) confirm the conclusion that salivary $\alpha$-amylase levels markedly increase in response to physical stress. Therefore, $\alpha$-amylase levels may be an effective non-invasive marker of physical stress.

\section{Acknowledgements}

This review was supported in part by the Ministry of Education, Culture, Sports, Science and Technology (MEXT)-Supported Program for the Strategic Research Foundation at Private 
Universities and a grant from the Research Project on Development of Agricultural Products and Foods with Health-promoting benefits (NARO), Japan.

\section{References}

1. Granger DA, Kivlighan KT, el-Sheikh M, Gordis EB and Stroud LR: Salivary alpha-amylase in biobehavioral research: recent developments and applications. Ann N Y Acad Sci 1098: 122-144, 2007.

2. Chatterton RT Jr, Vogelsong KM, Lu YC, Ellman AB and Hudgens GA: Salivary alpha-amylase as a measure of endogenous adrenergic activity. Clin Physiol 16: 433-448, 1996.

3. Kivlighan KT and Granger DA: Salivary alpha-amylase response to competition: relation to gender, previous experience, and attitudes. Psychoneuroendocrinology 31: 703-714, 2006.

4. Yamaguchi M, Hanawa N and Yoshida H: Evaluation of a novel monitor for the sympathetic nervous system using salivary amylase activity. Seitai-Ikougaku 45: 161-168, 2007 (in Japanese with English abstract).

5. Papacosta E and Nassis GP: Saliva as a tool for monitoring steroid, peptide and immune markers in sport and exercise science. J Sci Med Sport 14: 424-434, 2011.

6. Bishop NC, Walker GJ, Scanlon GA, Richards S and Rogers E: Salivary $\operatorname{Ig}$ A responses to prolonged intensive exercise following caffeine ingestion. Med Sci Sports Exerc 38: 513-519, 2006.

7. Allgrove JE, Gomes E, Hough J and Gleeson M: Effects of exercise intensity on salivary antimicrobial proteins and markers of stress in active men. J Sports Sci 26: 653-661, 2008.

8. Allgrove JE, Oliveira M and Gleeson M: Stimulating whole saliva affects the response of antimicrobial proteins to exercise. Scand J Med Sci Sports: March 19, 2013 (Epub ahead of print).

9. Fortes MB, Diment BC, Di Felice U and Walsh NP: Dehydration decreases saliva antimicrobial proteins important for mucosal immunity. Appl Physiol Nutr Metab 37: 850-859, 2012.

10. Fortes MB and Whitham M: Salivary Hsp72 does not track exercise stress and caffeine-stimulated plasma Hsp72 responses in humans. Cell Stress Chaperones 16: 345-352, 2011.

11. Leicht CA, Bishop NC and Goosey-Tolfrey VL: Mucosal immune responses to treadmill exercise in elite wheelchair athletes. Med Sci Sports Exerc 43: 1414-1421, 2011.
12. Costa RJ, Fortes MB, Richardson K, Bilzon JL and Walsh NP. The effects of postexercise feeding on saliva antimicrobial proteins. Int J Sport Nutr Exerc Metab 22: 184-191, 2012.

13. Rosa L, Teixeira A, Lira F, Tufik S, Mello M and Santos R: Moderate acute exercise $\left(70 \% \mathrm{VO}_{2}\right.$ peak) induces TGF- $\beta$, $\alpha$-amylase and IgA in saliva during recovery. Oral Dis: Feb 19, 2013. (Epub ahead of print).

14. de Oliveira VN, Bessa A, Lamounier RP, et al: Changes in the salivary biomarkers induced by an effort test. Int J Sports Med 6: 377-381, 2010.

15. Gallina S, Di Mauro M, D'Amico MA, D'Angelo E, Sablone A, Di Fonso A, Bascelli A, Izzicupo P and Di Baldassarre A: Salivary chromogranin A, but not $\alpha$-amylase, correlates with cardiovascular parameters during high-intensity exercise. Clin Endocrinol (Oxf) 75: 747-752, 2011.

16. Allgrove JE, Chapman M, Christides T and Smith PM: Immunoendocrine responses of male spinal cord injured athletes to 1-hour self-paced exercise: pilot study. J Rehabil Res Dev 49: 925-933, 2012.

17. Ishiguro C, Ikuta M, Sugita A, Okada T, Kozasa Y, Numata Y, Higashino T and Mikouchi N: The effect of the health education initiative 'Physical Exercise for Promotion of Health' on people in the community. Nihon Sekijuji Toyota Kango Daigaku Kiyo [Bulletin of Japanese Red Cross Toyota University of Nursing] 7: 107-119, 2012 (In Japanese).

18. Yamaguchi M, Deguchi M and Miyazaki Y: The effects of exercise in forest and urban environments on sympathetic nervous activity of normal young adults. J Int Med Res 34: 152-159, 2006

19. Bruce RA: Exercise testing of patients with coronary heart disease. Principles and normal standards for evaluation. Ann Clin Res 3: 323-332, 1971.

20. Chiodo S, Tessitore A, Cortis C, et al: Stress-related hormonal and psychological changes to official youth Taekwondo competitions. Scand J Med Sci Sports 21: 111-119, 2011.

21. Diaz MM, Bocanegra OL, Teixeira RR, Soares SS and Espindola FS: Response of salivary markers of autonomic activity to elite competition. Int J Sports Med 33: 763-768, 2012. 